\title{
Information and Communication Technology (ICT) Related Courses in the Department of Purchasing and Supply, Accra Polytechnic, Ghana: The Necessity and Significance of Change
}

\author{
David Oppong \\ Purchasing and Supply Department \\ School of Business and Management Studies \\ Accra Polytechnic, Ghana
}

\author{
Nana Yaw Asabere \\ Computer Science Department \\ School of Applied Sciences and Arts \\ Accra Polytechnic, Ghana
}

\begin{abstract}
Polytechnic Education was introduced in Ghana in the 1993/94 academic year. This introduction paved the way for different Higher National Diploma (HND) programmes to be run by various Polytechnics in Ghana. Due to the global importance of Supply Chain Management (SCM) and procurement in organizations, HND Purchasing and Supply was among the first Business programmes that Polytechnics in Ghana started running. Using relevant and existing literature, this paper describes the ICT content of the HND Purchasing and Supply curriculum in Accra Polytechnic, Ghana. Furthermore, the paper outlines the impact and significance of change in the ICT content of the HND Purchasing and Supply curriculum and discusses the importance of such changes in relation to previous contents and current global trends in terms of ICT.
\end{abstract}

\section{General Terms}

ICT, IT, Education, Polytechnic, Ghana

\section{Keywords}

Computer Literacy, Curriculum, HND, Purchasing and Supply, Procurement, Supply Chain Management (SCM)

\section{INTRODUCTION AND \\ BACKGROUND OF STUDY}

In the past few years, a growing number of organizations such as educational establishments, health centres/hospitals, telecommunication operators, pharmacies and oil companies, etc. have espoused the Supply Chain (SC) concept for the management of their daily business activities. The delivery system of these companies has become an integral part of the supplied product [1]. Supply Chain Management (SCM) has gained increasing prominence in recent years. SCM is an approach, which is being viewed by organizations in many sectors as a key source of competitive advantage [2]. Evangelista [1] emphasized that, the acceleration of physical and information flows along the multiple levels of the Supply Chain (SC) is making the whole logistical system more flexible, effective and efficient is responding to swift market changes. This scenario depicts the necessity for the merger of ICT and SCM in organizations and also corroborates the global importance of ICT related course contents within an $\mathrm{SCM}$ /procurement/purchasing and supply programme of a tertiary institution/higher education institution.
Following the enactment of the Ghana Polytechnic Law in 1992 i.e. PNDC Law 321, Accra Polytechnic ceased to exist in its previous form and became a tertiary institution. The PNDC Law 321 fully became operational in 1993/1994 academic calendar year and Accra Polytechnic was then placed under the Higher Educational Council with the autonomy to award Higher National Diplomas (HNDs) through the National Board for Professional and Technician Examination (NABPTEX), Ghana [3].

The mission of Accra Polytechnic as well as other sister Polytechnics in Ghana is: to provide life transforming opportunities and experiences for students through teaching, research, practical training and entrepreneurial skills development in the fields of Applied Sciences, Applied Arts, Business, Engineering and Technology for the benefit of the society. Furthermore the vision of Polytechnic education in Ghana is to become centres of excellence for teaching, practical training, learning and research [3].

The above mission substantiated the introduction of three main schools in Accra Polytechnic, namely, School of Applied Sciences and Arts, School of Business and Management Studies and School of Engineering. In the School Business and Management Studies, there are four departments, namely Accountancy, Marketing, Purchasing and Supply and Liberal Studies. The chronological flow of the Department of Purchasing and Supply within the School of Business and Management studies is depicted below in Figure 1. The Department of Purchasing and Supply currently offers a three year HND Programme in Purchasing and Supply. The main objective of the HND Purchasing and Supply Programme is to enhance students interested in reading procurement as a profession, in order for them to attain goals and make them marketable in the Ghanaian market after completion of studies. The Department has

Table 1. Student Enrolment as at 2012/2013 Academic Year

\begin{tabular}{cccc}
\hline Year & $\begin{array}{c}\text { HND }- \\
\text { Full Time }\end{array}$ & $\begin{array}{c}\text { HND }- \\
\text { Part } \\
\text { Time }\end{array}$ & $\begin{array}{c}\text { Diploma in Business } \\
\text { Studies (Purchasing and } \\
\text { Supply) }\end{array}$ \\
\hline $\mathbf{1}$ & 388 & 310 & 68 \\
\hline $\mathbf{2}$ & 320 & 112 & 120 \\
\hline $\mathbf{3}$ & 395 & 137 & - \\
\hline Total & $\mathbf{1 1 0 3}$ & $\mathbf{5 9 9}$ & $\mathbf{1 8 8}$ \\
\hline
\end{tabular}




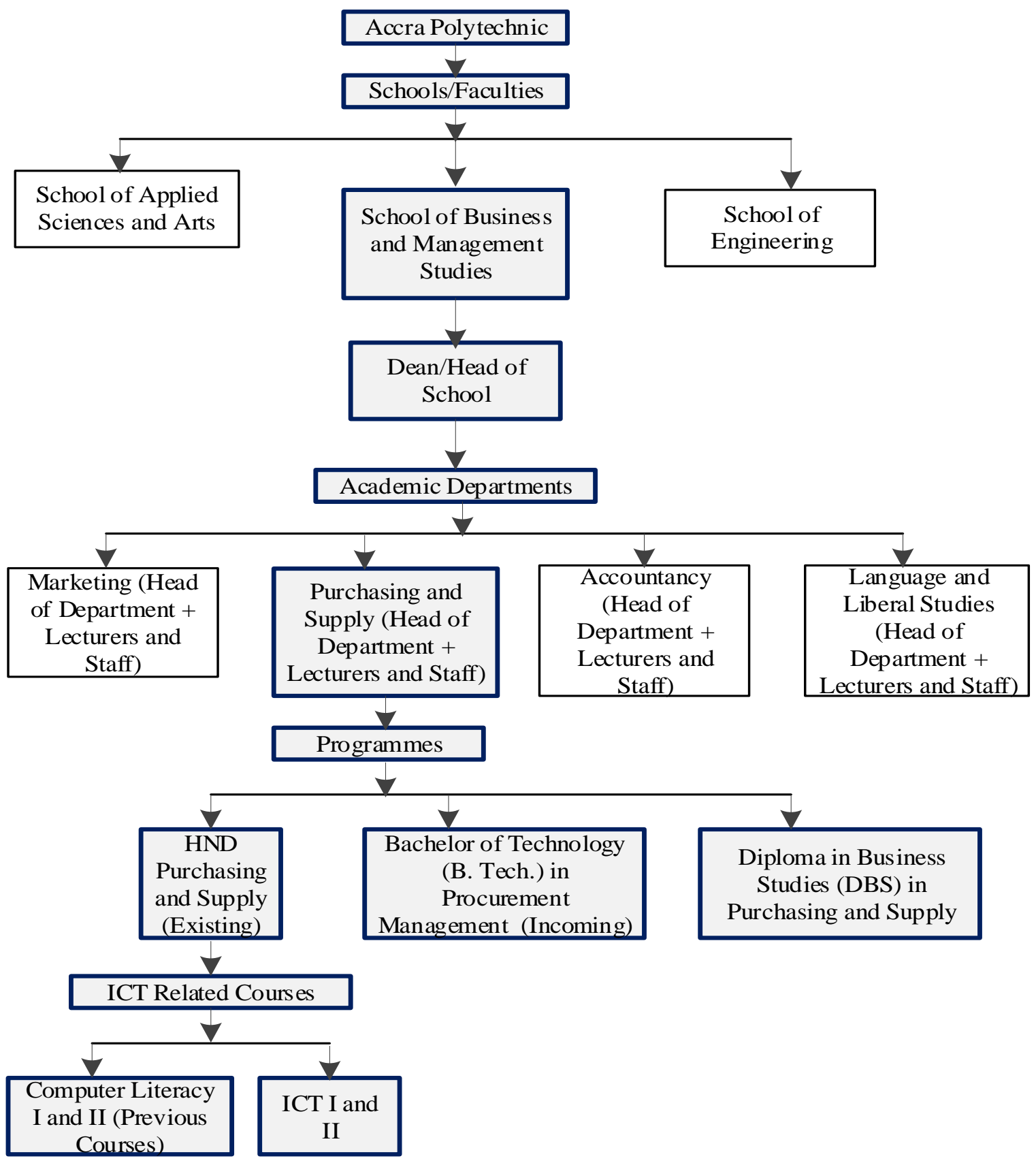

Fig. 1: Chronological Flow of the Department of Purchasing and Supply, Accra Polytechnic, Ghana

twelve (12) full time lectures and two (2) administrative staff members [4]. The breakdown of the current students within the department is depicted in Table 1 [4]. The Department of Purchasing and Supply started operating a new curriculum with the 2011/2012 batch of students, which resulted in the fading away of the previous syllabus/curriculum. The new syllabus/curriculum is expected to help students apply for exemptions with The Chartered Institute of Purchasing and Supply (CIPS), UK. In addition to making the Department more stronger in terms of input to students and resultant output to the Ghanaian community, the Department of Purchasing and Supply has made successful strides and worked diligently to introduce the B. Tech. programme in Procurement Management and plans are far in advance to achieve this pursuit/mission [4].

Regarding the change in the HND Purchasing and Supply curriculum, a major innovation that was effected involved changes pertaining to the ICT related courses. Previous courses that were facilitated by the Computer Science Department at Accra Polytechnic were Computer Literacy I and II (CLT 101 and CLT 102) for first and second semesters respectively [5]. Currently these courses have been replaced with ICT I and ICT II (PUS 205 and PUS 206) also for first and second semesters respectively [4].

This paper focuses on the significance and necessity of these changes. Additionally, the paper outlines the reasons and justification for such changes and its resultant effect on the teaching staff, students and Ghana as a whole. The rest of the paper is organized as follows: A Review of Literature is presented in Section 2. Section 3 presents a discussion on the issues pertaining to previous and current ICT Related Courses in the HND Purchasing and Supply Curriculum. 
Section 4 elaborates on Research Discussion and Analysis and Section 5 finally concludes the paper with a Recommendation and outlines some Future Work.

\section{LITERATURE REVIEW}

This Section of the paper reviews relevant and existing literature pertaining to the subject matter. Initially, the paper reviews Supply Chain (SCM) Management and Procurement, then ICT/IT and SCM and finally ICT/IT and Procurement. The review shows the relationship between ICT/IT, Procurement and SCM as well as the importance and necessity of ICT/IT in SCM and procurement in the industrial global world. Additionally, the review ascertains the actual ICT/IT needs in a SCM or procurement curriculum of an institution to corroborate the importance of the significant changes in a curricula, which is this focus of this paper.

\subsection{SCM and Procurement}

\subsubsection{SCM}

A supply chain consists of a series of organizations, each of which adds value by performing a number of tasks in series or parallel. The chain starts with a raw material and ends with a final consumer [6]. According to Muffatto et al. [7], the supply chain, a term now commonly used internationally, incorporates every effort involved in producing and delivering a final product or service, from the supplier of raw materials to the consumer/customer. Handfield and Nichols [8] stated that the supply chain 'encompasses all those organizations and activities associated with the flow and transformation of goods from the raw material stage, through to the end user, as well as the associated information flow'. Handfield and Nichols [8], further defined Supply Chain Management (SCM) as "the integration and management of supply chain organizations and activities through cooperative organizational relationships". Muffatto et al. [7] also emphasized that SCM includes managing supply and demand, sourcing raw materials and parts, manufacturing and assembly, warehousing and inventory tracking, order entry and order management, distribution across all channels and delivery and transportation to the customer.

Jespersen and Skjott-Larsen [9] argued that the competitiveness of international companies is highly dependent on their ability to deliver customized products

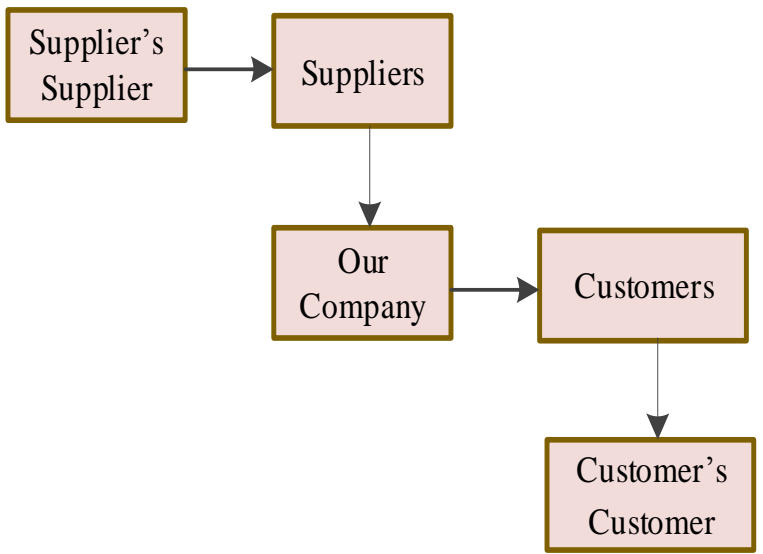

\section{Fig. 2: A Typical Supply Chain of a Company}

quickly and timely all over the world. As a consequence, the focus has moved from competition between firms at the same level in the production process to competition between supply chains, from raw materials to end customers. Harris and Botten [6] explained that linkages within the supply chain are either upstream or downstream. These terms relate to the direction of flow in the supply chain, therefore downstream refers to towards the customer, and upstream refers to towards the supplier. From a purchasing perspective, the supply chain processes are as follows: Search, Acquire, Use, Maintain and Dispose. From the supplying perspective, the processes are: Research, Design, Manufacture or Provide, Sell and Service. Supply chains are often described diagrammatically, as shown in the Figure 2.

According to Cox and Lamming [10], the view of a supply chain being a series of dyadic (one-to-one) relationships is based on a model of business dating from the nineteenth century. At that time, the manner in which firms dealt with one another reflected their competencies. In other words, each organization used their own skills as part of a joint wish to provide products to the end consumer, and a commercially based respect for the technical capabilities available from both companies. Mass production principles destroyed this model, and replaced it with a high volume model serving consumers that were easily led and presented manufacturers with a ready tempting opportunity for exploitation. This meant that for the first three quarters of the twentieth century, the mass producers could thus force their "vanilla" products upon their sales markets [10]. There was therefore no incentives for organizations to have any kind of sophisticated relationship with their compliant supply market, particularly where the purchaser had a wide spread of potential suppliers who could be controlled in one of two ways below:

- By being bought, leading to the development of vertically integrated mass production.

- By extracting their expertise under threat of the loss of business.

There are some academic arguments as to whether it is reasonable to view the supply chain as a chain. Many definitions, indeed, cannot help referring to the supply chain as something other than a chain. For example, a supply chain is a network of organizations'.

Harland [11] discussed four different applications of the term supply chain. These are:

1. The internal supply chain, which integrates business functions involved in the flow of materials and information from inbound to outbound.

2. A dyadic (or two-party relationship) between a supplier and a customer.

3. A series of businesses, including an organization, its supplier, its supplier's supplier, its customer and its customer's customer, and so on.

4. A network of interconnected businesses involved in the ultimate provision of product and service packages required by end customers.

Lamming et al. [12] suggested that there are three factors driving the way supply networks should be managed:

1. Whether the product is innovative or functional. An innovative product is one with unpredictable demand and a short product life cycle.

2. Whether the product is unique i.e. valuable, rare and difficult to imitate.

3. The degree of complexity of the product.

\subsubsection{Procurement}

Procurement consists of all the activities involved in acquiring goods or services and managing their flow from the supplier 
within the organization/company which is purchasing the goods or services to the semi-finished products and support materials, such as computers, air conditioners and office supply products, which the organization/company uses [7][13][14].

Lancioni et al. [15], outlined and summarized the stages of a procurement process through the following points:

- The need to procure a particular good or service.

- The search for potential suppliers and the definition of other possible alternatives.

- Evaluation of the alternatives.

- Contact with suppliers to begin the negotiating process.

- Evaluation of the offers.

- Agreement on the type of supply:

- Standardized products,

- Products for which project specifications must be given,

- Products which are designed together with the suppliers.

- An agreement is reached.

- A contract is drawn up.

- The contract is signed and the order sent.

- Goods and services are transferred in exchange for money or other forms of compensation.

Due to the fact that procurement is a key process in the Supply Chain, the advent of the Internet has led to the redesigning and reorganization of procurement processes in various organizations [16]. The new forms of procurement which take advantage of ICT in order to digitize certain stages of these processes is called e-procurement, which will further be discussed and defined in Section 2.3.

\subsection{ICT/IT and SCM}

A review of the existing literature shows that there are abundance of papers dealing with ICT/IT in SCM. For example Johnson and Whang [17] and Gunasekaran and Ngai [18] respectively presented literature reviews on the subject, although neither of them reviewed very broadly. Common terms for business models using ICT/IT are "e-commerce" and "e-business" - the former relating typically to web-based sales, and the latter to a more holistic use of ICT/IT [19]. According to Christiaanse et al. [20], the notion of competitive advantage of supply chains and consequently Supply Chain Management (SCM) is a relatively recent idea in management literature. Additionally, Christiaanse et al. [20] emphasized that three (3) factors have contributed to the necessity for managing the supply chain. On the demand side, an increasingly cost- and value-conscious customer is demanding more, varied, often personalized value from the supply chain. On the supply side, the availability of modern Information and Communication Technologies (ICT) makes it possible to obtain an overview of the entire supply chain and to redesign and manage it in order to meet this demand. Finally, on both the demand and supply side, the emergence of global markets and global sourcing have stretched these supply chains over intercontinental distances. Innovative use of ICT can significantly change the cost and value equation for a supply chain [21].

Initial efforts to support SCM through ICT have centered on the management of demand doubt through inventory demand forecasting and reduction of inventory and transportation costs and/or cycle times through optimization techniques. Generally described under the umbrella term "Advanced Planning Systems" (APS), these applications provide decision support by using operational data to analyze and optimize the flows through the supply chain [21]. Techniques deployed in APS include, optimization techniques (linear programming, mixed integer programming, location allocation techniques, and genetic and rule-based algorithms) scenario planning (what-if analysis and simulations), forecasting and time series analysis [21]. Increased computing power has enabled the use of these sophisticated optimization algorithms in complex real-life supply chain situations. APS systems represent a quantitative model driven perspective on the use of ICT in supporting SCM [21].

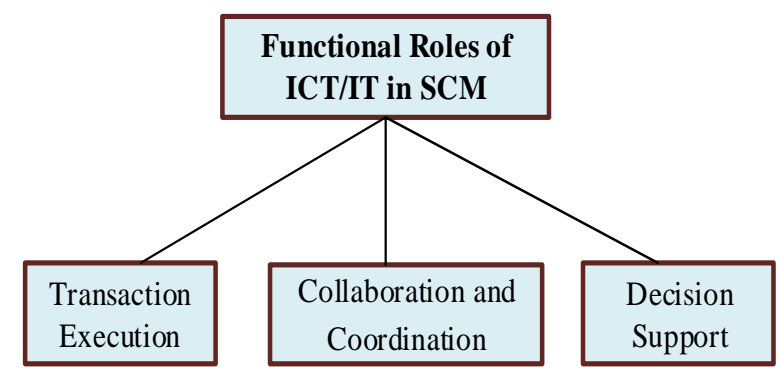

Fig. 3: Functional Roles of ICT/IT in SCM

Simchi-Levi et al. [22] stated that the objectives of ICT/IT in SCM are:

- To provide information availability and visibility;

- To enable a single point of contact for data;

- To allow decisions based on total supply chain information; and

- To enable collaboration with supply chain partners.

Moshowitz [23], stated that the introduction of ICT has made it possible to search for and contract with partners on a global scale, to switch partners according to the needs defined by the market opportunity, and to develop and implement a variety of flexible supply chain design options that can create substantial cost and value advantages [20]. Thus, in contrast to the model-based ICT support for SCM inherent in APS, emerging business phenomenon and experiences in the field are likely to drive the next generation of ICT-based supply chain applications [21].

The commonly viewed and adoptable functional roles of ICT/IT in SCM, are depicted in Figure 3. In Figure 3, the three main functional roles of ICT/IT in SCM are: (i) Transaction Execution, (ii) Collaboration and Coordination and (iii) Decision Support. Cross [24] accentuated that the most typical role of ICT/IT in SCM is reducing the friction in transactions between supply chain partners through costeffective information flow.

Conversely, ICT/IT is more importantly viewed to have a role in supporting the partnership and coordination of supply chains through information sharing. For instance, Lee and Whang [25] presented ICT/IT as one of the key cures for the bullwhip effect in supply chains. ICT/IT can also be used for decision support. In this instance the analytical power of computers is used to provide assistance in managerial decisions. Simchi-Levi et al. [22] and Swaminathan and Tayur [26] reviewed analytical models in the supply chain management literature and provided a detailed discussion of decision support systems for SCM.

According to Auroma et al. [19], the benefits of ICT/IT in SCM are manifold, and can vary according to the implementation method. Furthermore, the use of ICT/IT is closely related to process changes. Therefore, SCM can be viewed as a process change that is helped or enabled by ICT/IT. This makes it difficult, or even in many cases a 


\begin{tabular}{|c|c|c|}
\begin{tabular}{|l|} 
Phase 1 \\
ICT/IT \\
Technologies \\
in SCM
\end{tabular} & $\begin{array}{c}\frac{\text { Phase 2 }}{\text { ICT/IT }} \\
\text { Solutions in } \\
\text { SCM }\end{array}$ \\
\hline
\end{tabular}

Fig. 4: Data Collection Phases of ICT/IT in SCM

necessary academic exercise, to separate the origin of the SCM benefit, whether derived from ICT/IT, process change, or a combination of both. Additionally, Auroma et al. [19], outlined three main data collection phases of ICT/IT in SCM. This is depicted in Figure 4. The three data collection phases include: (i) ICT/IT technologies in SCM, (ii) ICT/IT solutions in SCM and (iii) Benefits of ICT/IT in SCM.

\subsection{ICT/IT and Procurement}

\section{(E-Procurement)}

Electronic Business (E-Business) involves processes that use Internet technology to simplify certain activities in an organization in order to improve productivity and increase efficiency. E-Business allows organizations to communicate more easily with their suppliers as well as buyers and customers. Johnson and Whang [27] defined E-Business as the marriage between the Internet and supply chain integration. This marriage is transforming many processes within the supply chain, for example, from procurement to customer management and product design [27].

The introduction and adoption of ICT in both private and public sector businesses such as Commerce, Procurement and Banking and the diffusion of the Internet among the general population have resulted in a rising level of comfort and familiarity with the electronic technologies in many contexts [28]. As a result, many governments have invested huge amounts of money and capital to develop ICT/IT infrastructure and deploy ICT/IT to serve their stakeholders in an efficient and effective way [29]. According to Kaliannan and Awang [29], e-procurement (the activity of procurement using ICT) has become an important management tool for enhancing the performance of supply chain especially in the global public sector.

The Internet is an ICT which has been used above all in Business-to-Business (B2B) relationships of various organizations worldwide. The advent of the Internet has enabled the possibility of efficient and quick management of many relationships by various organizations. Some of these relationships involve purchasing semi-finished products, components and equipments, interacting with wholesalers, taking on new resources and providing services and technology [29][30].

Electronic Procurement (E-Procurement) can therefore be defined as all of those activities in organizations/companies that require the procurement of goods or services through the support of the Internet, or in general ICT [31][32]. EProcurement technologies such as E-Procurement software, B2B auctions, B2B market exchanges and purchasing consortia are focused on automating workflows, uniting and leveraging organizational spending power, and identifying new sourcing opportunities through ICT and the Internet [30]. The benefits and advantages of E-Procurement have already been proven in a number of studies [33][34]. These studies emphasized that E-Procurement enables organizations to distribute operational procurement processes and centralize strategic procurement processes as a result of the higher supply chain transparency provided by E-Procurement systems.
Characteristically, a company's procurement function is subdivided into strategic and operational processes, since activities and priorities in these two areas are entirely different [35][36]. Supplier management, the pooling of purchase requisitions and procurement-oriented product development are tasks that are typically assigned to strategic procurement [37]. Before the advent and introduction of E-Procurement, strategic procurement often included administrative routine work, such as individual transactions, converting purchase requests into purchase orders or ensuring the correct allocation of invoices received. Strategic aspects are frequently neglected in the process, with the buyer having little influence over the choice of suppliers and the purchased products [37].

The use of Internet technologies in procurement is aimed at realizing faster and more efficient operational procurement processes which bypasses the purchasing department of organizations and enable those people to concentrate on more strategic tasks. This scenario is depicted in Figure 5 [38]. In E-Procurement, requesters directly search for and select products in electronic catalogs which are authorized and negotiated by strategic procurement in advance [37].

Reduction of Operational Functions

\begin{tabular}{|c|c|c|}
\hline $\begin{array}{c}\text { Strategic } \\
\text { Procurement }\end{array}$ & $\begin{array}{c}\text { Supplier } \\
\text { Management }\end{array}$ \\
\hline Maximize & Minimize \\
\hline Strategic Procurement & $\begin{array}{c}\text { Operational Functions } \\
\text { Functions }\end{array}$ \\
\hline
\end{tabular}

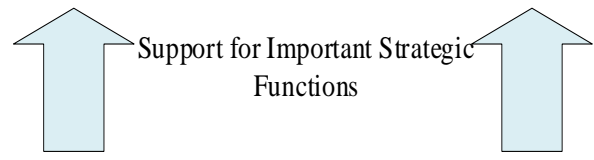

Fig. 5: Effects of E-Procurement

\section{ICT/IT RELATED COURSES IN THE CASE STUDY DEPARTMENT}

This Section of the paper discusses both past and present ICT related courses in the Department of Purchasing and Supply, Accra Polytechnic. Additionally, an elaboration on the individual modules and course components are presented. Furthermore, the paper deliberates on the reasons for the change of ICT related courses in the HND Purchasing and Supply curriculum.

\subsection{Computer Literacy I and II (CLT 101 and CLT 102) - Previous Curriculum}

As mentioned in Section I, the commencement of tertiary education by Polytechnics in Ghana paved the way for the introduction of various HND programmes. All the HND programmes were designed with a curricula that involves specific mandatory courses. Some of these courses include: Communication Skills, African Studies and Computer Literacy. Therefore, Computer Literacy I and II, with course 
codes CLT 101 and CLT 102, were the ICT courses introduced to help Polytechnic students gain knowledge regarding computers systems and their usage. The general aim of the Computer Literacy courses in the various HND Programme curricula is for students to: (i) learn and gain knowledge of the basic parts of the computer system and how the parts are interrelated to function as an electronic machine and (ii) learn and gain knowledge about related software applications [5]. Tables 2 and 3 [5] depict more details about the previous Computer Literacy courses in Department of Purchasing and Supply, Accra Polytechnic, for first and second semester of an academic year respectively.

Table 2: Computer Literacy I (CLT 101: First Semester) - Course Information

\begin{tabular}{ll}
\hline \multicolumn{1}{c}{ Course } & \multicolumn{1}{c}{ Summarized Description } \\
\hline 1.0: Computer & Understanding the Basic Computer \\
Operation Skills & Terminologies, Recognizing and \\
& Explaining the Functional Parts of \\
& the Computer System, Using, \\
& Connecting and Setting up Basic \\
& Components of a Computer, \\
& Booting and Shutting Down \\
& Computers, Using and Repairing \\
& Essential Computer Resources and \\
& Backing up Copies of Documents
\end{tabular}

2.0: Elements of Ensuring System Security Rules,
Computer Security Setting Up Physical Security, Planning Procedural Security, Knowledge Discovery, Computer Ethics and Professionalism Procedures.

3.0: Word Processing
Application Software
(Microsoft Word)

Identifying Features and
Advantages of Word Processing, Creating an MS Word Document and Formatting and Editing Using MS Word.

\begin{tabular}{ll}
\hline 4.0: Presentation & Identifying Features and \\
Software (Microsoft & Advantages of MS PowerPoint, \\
PowerPoint) & Creating an MS PowerPoint \\
& Presentation and Formatting and \\
& Editing Using MS PowerPoint.
\end{tabular}

\subsection{ICT I and II (PUS 205 and PUS 206) - New/Current Curriculum}

The survival of any company or organization depends not only on the efficient and accurate production of goods and services to meet customer requirements but also (and more importantly) on the rapid and accurate processing and distribution of information [4]. Due to this reason the Department of Purchasing and Supply, Accra Polytechnic, envisioned the necessity of improving and elevating the Computer Literacy courses to enhanced-ICT courses.

In [4] an outline is presented on the course objectives for ICT, which consists of: (i) students are expected to be conversant with the acquisition, processing, storage and dissemination of numerical, pictorial, vocal, microelectronics and contextual based information in the practice of procurement and SCM and (ii) students are also expected to be a able to manage the risks associated with electronic systems in procurement.

Additionally, after fulfilling the requirements of the ICT I and II, students are expected to: (i) be conversant and have skills regarding effective use of spreadsheet applications for
procurement/SCM,/purchasing and supply functions, (ii) appreciate benefits of Electronic Data Exchange (EDE), (iii) appreciate the contribution of ICT as a tool for the national development of Ghana as well as global development and (iv) appreciate the benefits of Electronic Point of Sales (POS) to buyers and sellers. Tables 4 and 5 [4] shows more details about the current ICT courses in the in Department of Purchasing and Supply, Accra Polytechnic for the first and second semesters of an academic year respectively.

Table 3: Computer Literacy II (CLT 102: First Semester) - Course Information

\begin{tabular}{ll}
\hline \multicolumn{1}{c}{ Course } & \multicolumn{1}{c}{ Summarized Description } \\
\hline $\begin{array}{l}\text { 1.0: Spreadsheet } \\
\text { Application Software } \\
\text { (Microsoft Excel) }\end{array}$ & $\begin{array}{l}\text { Identifying Features and } \\
\text { Benefits of Spreadsheets, } \\
\text { Creating an MS Excel } \\
\text { Workbook and Formatting and } \\
\text { Editing Using MS Excel. }\end{array}$ \\
\hline $\begin{array}{l}\text { 2.0: Database } \\
\text { Application Software } \\
\text { (Microsoft Access) }\end{array}$ & $\begin{array}{l}\text { Identifying Features and } \\
\text { Benefits of DBMS, Creating an }\end{array}$ \\
& $\begin{array}{l}\text { Formatting and Editing Using } \\
\text { MS Access. }\end{array}$ \\
\hline 3.0: Programming & $\begin{array}{l}\text { Differentiating Between High } \\
\text { and Low Level Programming }\end{array}$ \\
& $\begin{array}{l}\text { Languages, Programming in } \\
\text { BASIC and Formula } \\
\text { Translation }\end{array}$ \\
& Executing/Running (Fortran), \\
& Debugging a Program. \\
\hline 4.0: Internet & $\begin{array}{l}\text { Identifying Knowledge About } \\
\text { the Internet, Using the Internet } \\
\text { for Transactions Such as Web }\end{array}$ \\
& Search and E-Mail, Chatting \\
and Downloading and Using the \\
Internet for Academic \\
Activities.
\end{tabular}

\subsection{Justification, Necessity and Significance of ICT Related Course Changes}

With reference to the literature reviewed in this paper, it can be realized that the relationship between ICT/IT and $\mathrm{SCM} /$ procurement/purchasing and supply is very phenomenal and important. Additionally, the benefits of ICT/IT in SCM as well as the introduction of ICT in procurement have paved the way for organizations to perform various transactions involving SCM and procurement in a more efficient way. Figure 3 (Functional Roles of ICT/IT in SCM) depicts that without ICT/IT, SCM will not function at its best and resultant outputs in terms of products will always be better through the incorporation of ICT. Furthermore, with reference to Figure 5 (Effects of E-Procurement), it can additionally be realized that E-Procurement introduces a reduction of operational functions and supports important strategic functions. The operational functions are reduced as a result of the introduction of ICT/IT tools/components which helps and benefits the procurement process.

Consequently, in order for organizations to utilize ICT/IT in SCM effectively, there is the need for accurate and required manpower. Referring to, Tables 2 and 3, the Computer Literacy course components cannot meet such requirements 
Table 4: ICT I (PUS 205: First Semester) - Course Information

Table 5: ICT II (PUS 206: Second Semester) - Course Information

Course

1.0:

Introduction to

Computers

2.0: E-

Procurement
Summarized Description

Hardware, Software, Programming and Application Packages.

Business-to-Customer (B2C) ECommerce, Business-to-Customer (B2C) E-Commerce, Online Marketing, Website Design and Application, ICT as a Competitive Tool, ICT in Modern Industry, Point of Sales (POS) Terminals, ICT and National Development.

3.0: Internet

The Importance of Internet, WWW, Risk of the Internet, Inappropriate use of the Internet, The Internet and E-Commerce, Wide Area Networks (WANs), Internet Policies of Organizations and Intellectual Property Consideration of the Internet.
Course

1.0: Intranet

1.0. Intranet

2.0: E-Mails

3.0: ICT Packages

4.0: Information Security Threats

\section{Summarized Description}

Local Area Networks (LANs), How Intranet Supports Internal Applications, Computer Crimes and Intranet Applications for ECommerce.

Characteristics of E-Mail, Dos and Don'ts in E-Mail and Precautions in E-Mail.

Telecommunication equipment, Business and Executive Support Packages, Data Integrations, Copyrights and ICT Packages and Contracting for ICT Packages

Confidentiality, Availability, Computer Virus, Integrity, Firewall Technology, Internet Security, Secure Electronic Payment System and Electronic Copyright Consideration.

because activities and phases involved in SCM necessitate more knowledge in ICT. The Computer Literacy courses, although quite relevant to SCM, purchasing and supply and procurement, are fundamental in terms of the computing knowledge required to for the current prospects of ICT/IT in SCM and procurement. An observation of current global ICT/IT trends corroborates its importance in SCM and procurement. Due the these reasons, the Department of Purchasing and Supply, Accra Polytechnic as well as other sister polytechnics recognized the necessity and significance of enhancing the ICT related courses in the HND Purchasing and Supply curricula. This change will go a long way to improve the SCM and procurement practices of organizations in Ghana, because students will become more efficient in using and applying ICT for procurement and purchasing and supply functions. Figure 6 depicts a simple diagram of the changes in ICT related courses in the Department of Purchasing and Supply, Accra Polytechnic.

\section{RESEARCH ANALYSIS AND DISCUSSIONS}

As a result of the tremendous proliferation of ICT trends and the Internet, various organizations are adopting activities that are ICT-oriented. A comparison between Tables 2 and 3 and Tables 4 and 5, which respectively depicts both previous and new first and second semester ICT related courses, validates an improvement which conforms to the requirements of industrial organizations as stipulated in this paper. Tables 4 and 5 shows that the new ICT course contents in the current

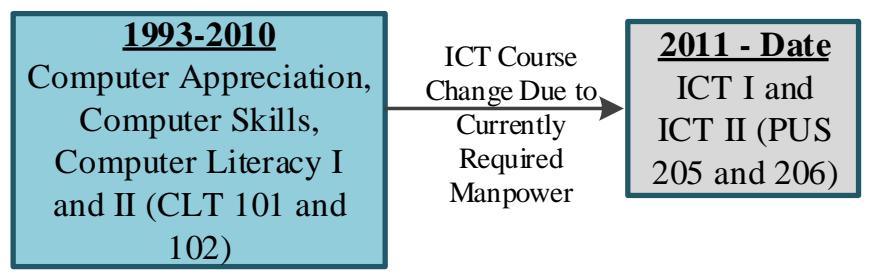

Fig. 6: A Simple Illustration of ICT Related Course Change in the Department of Purchasing and Supply, Accra Polytechnic, Ghana
HND Purchasing and Supply curriculum in more beneficial, in the sense that students will gain more and enhanced knowledge in ICT in comparison to the knowledge gained from the previous Computer Literacy courses. Additionally, the course components of ICT I and II (PUS 205 and 206) will make the students more competent in terms of ICT usage and skills. That notwithstanding, it can further be observed that part of the Computer Literacy course components (CLT 101 and 102) have been absorbed in ICT I and II (PUS 205 and 206). This signifies that the Computer Literacy course hasn't been wiped out completely but has rather been redesigned and enhanced/improved to meet current ICT requirements for SCM and procurement.

With reference to Tables 2 and 3, it can be vividly seen that the previous ICT Related courses (Computer Literacy I and II) in the Department of Purchasing and Supply, Accra Polytechnic didn't have ICT contents related to SCM and procurement. A critical look at the first semester of ICT I (PUS 205) depicts essential courses such as E-Procurement and Internet which are not present in both semesters of the Computer Literacy Courses in Tables 2 and 3. Additionally, the Introduction to Computers course in Table 4, caters for almost all the course components in Table 2, with the exception of Elements of Computer Security i.e. the course descriptions for the Introduction to Computers in Table 4 involves both hardware and software as well as application packages. Therefore the students will learn all the required elementary application softwares such as MS Word, MS Excel, MS PowerPoint and MS Access and continue to study/learn E-Procurement and the Internet to further enhance their knowledge. Furthermore, in Tables 2 and 3, elementary application softwares have been divided between the two semester i.e. MS Word and MS PowerPoint for First Semester and MS Excel and MS Access for second semester. These divisions don't leave enough time and room for the incorporation of more ICT courses related to SCM and procurement. Consequently, a critical look at Table 5 (ICT II - PUS 206) depicts newer and innovative ICT courses that are related to SCM and procurement. These courses include ICT 
Packages, Information Security Threats, Internet and E-Mails. Such courses will influence and help/aid students of the Department more in terms of increasing their ICT knowledge towards SCM and procurement. In a nutshell, the current ICT related courses of the Department of Purchasing and Supply, Accra Polytechnic, look more innovative and will help students of the Department gain enhanced ICT knowledge in the field of ICT and procurement in comparison to the previous ICT related course components. However, the ICT related courses in the case study Department were recently changed, how effective this change will be in terms of output in the Ghanaian society still remains to be seen and realized.

\section{CONCLUSION}

This paper presented a descriptive overview of the ICT related courses in the Department of Purchasing and Supply in Accra Polytechnic, Ghana. Through review of relevant, existing and related literature, the paper outlined the importance, relationship and benefits of ICT/IT in both SCM and Procurement. Furthermore, the paper corroborated the importance of ICT in SCM and procurement by elaborating and describing the differences of the ICT related course components in the HND Purchasing and Supply curricula of the case study Department. A critical analysis and comparison of the previous and current ICT related courses in the curricula shows that the current curricula is justified and is on the right track in terms of SCM and procurement operations/activities of organizations.

Consequently, this paper recommends that the facilitation/lecturing of the current ICT related courses (ICT I and II) to students should continue in order to conform to the needs and requirements of organizations in terms of SCM and procurement performance. Furthermore, as a future work, the case study Department should verify the output of the current ICT related courses in organizations in comparison to the previous ones in order to determine whether there are some weaknesses or lapses and solve them accordingly. Additionally, a critical research analysis of both organization and student views through qualitative and quantitative research methodologies involving the current ICT/IT related courses should also be conducted by the teaching staff of the Department to ascertain whether improvements and amendments can or should be made for efficient and effective ICT/IT lecture delivery.

\section{REFERENCES}

[1] P. Evangelista, "The Role of ICT in the Logistics Integration Process of Shipping Lines", Pomorski Zbornik (1), pp. 61-78, 2002.

[2] E. Sweeney, "Managing the Supply Chain: the Role of Information and Communications Technology (ICT) as a Key Enabler of the Process, Business Ireland, Summer Issue, pp.105-109, 2005.

[3] Accra Polytechnic, Ghana, Retrieved 29/07/2013, From: www.apoly.edu.gh

[4] Document on the Review of HND Purchasing and Supply Curriculum in Ghana Polytechnics, Unpublished Draft, 2009-2011.

[5] J. Aryeetey, F.K. Dogbey and R.T. Adanu, "Computer Literacy Course Curriculum for Polytechnics in Ghana", Unpublished Draft.

[6] R. D. Harris and N. Botten, "Strategic Supply Chain Management", Easton House, 2006.
[7] M. Muffatto and A. Payaro, "Implementation of EProcurement and E-Fulfillment Processes: A Comparison of Cases in the Motorcycle Industry,".International Journal of Production Economics, 89(3), Elsevier, pp. 339-351, 2004.

[8] R.B. Handfield and E.L. Nichols, "Supply Chain Redesign: Transforming Supply Chains into Integrated Value Systems". Prentice Hall, 2002.

[9] D. Jespersen and B. T. Skjott-Larsen, "Supply Chain Management", Copenhagen Business School, 2005.

[10] A. Cox and R. Lamming, "Managing Supply in the Firm of the Future", European Journal of Purchasing and Supply Management, Vol. 3, No. 2, pp. 53-62, 1997.

[11] C. M. Harland, "Supply Chain Management: Relationships, Chains and Networks", British Journal of Management, Vol. 7, No. 1, pp. 63-80. 1996.

[12] R. Lamming, T. Johnsen, J. Zheng, and Harland, "An Initial Classification of Supply Networks", International Journal of Operations and Production Management, Vol. 20, No. 6, pp. 675-691, 2000.

[13] H. E. Hough, , J. M. Ashley, "Handbook of Buying and Purchasing Management", Prentice-Hall, Englewood Cliffs, NJ, 1992.

[14] G. Zenz and G. H. Thompson, "Purchasing and the Management of Materials", 7th Edition, Wiley, New York, 1994.

[15] R.A. Lancioni, M.F. Smith, and T.A. Oliva, "The Role of the Internet in Supply Chain Management," Industrial Marketing Management, (29), pp. 45-56, 2000.

[16] D.M. Lambert, M.C. Cooper, and J.D. Pagh "Supply Chain Management: Implementation Issues and Research Opportunities," International Journal of Logistics Management, Vol. 9, No. 2, pp. 1-19, 1998.

[17] M. E. Johnson, and S. Whang, "E-Business and Supply Chain Management: An Overview and Framework", Production and Operations Management, Vol. 11, No. 4, pp. 413-423, 2002.

[18] A. Gunasekaran, and E.W.T. Ngai, "Information Systems in Supply Chain Integration and Management", European Journal of Operational Research, Vol. 159, pp. 269-95, 2004.

[19] J. Auramo, J. Kauremaa, and K. Tanskanen, "Benefits of IT in Supply Chain Management: An Explorative Study Of Progressive Companies", International Journal of Physical Distribution \& Logistics Management, Vol. 35, No. 2, pp. 82-100, 2005.

[20] E. Christiaanse and K. Kumar, "ICT-enabled Coordination of Dynamic Supply Webs," International Journal of Physical Distribution and Logistics Management 30, (3/4), pp. 268-285, 2000.

[21] K. Kumar, "Technology for Supporting Supply Chain Management: Introduction", Communications of the ACM, Vol. 44, No. 6, pp. 58-61, 2001.

[22] D. Simchi-Levi, P. Kaminsky, and E. Simchi-Levi, "Designing and Managing the Supply Chain: Concepts, Strategies, and Case Studies," McGraw-Hill, New York, NY., 2003. 
[23] A. Moshowitz, "Virtual Organization" Communications of ACM, Vol. 40, No. 9, pp. 30-37, Sept. 1997.

[24] G.J. Cross, "How E-Business is Transforming Supply Chain Management", Journal of Business Strategy, Vol. 21 No. 2, pp. 36-9, 2000.

[25] H. Lee and C, Whang, "Bullwhip Effect in Supply Chains," Sloan Management Review, Vol. 38 No. 3, pp. 93-102, 1997.

[26] J. M. Swaminathan and S.R Tayur, "Models for Supply Chains in E-Business," Management Science, Vol. 49 No. 10, pp. 1387-406, 2003.

[27] M. E. Johnson and S. Whang, "E-Business and Supply Chain Management: An Overview and Framework," Production and Operations management, 11(4), pp. 413-423, 2002.

[28] Z. Ebrahim and Z. Irani, "E- Government Adoption: Architecture And Barriers. Business Process Management Journal, Vol. 11, No. 5, pp. 589-611, 2005.

[29] M. Kaliannan and H. Awang, "Adoption and use of EGovernment Services: A case study on E-procurement in Malaysia,"WSEAS Transactions on Business and Economics, Vol. 7, Issue 1, 2010.

[30] A. Davila, M. Gupta, and R. Palmer, "Moving Procurement Systems to the Internet:: the Adoption and Use of E-Procurement Technology Models," .European Management Journal, Vol. 21, No. 1, pp. 11-23, 2003.

[31] J. Gebauer, C. Beam, and A. Segev, "Impact of the Internet on Procurement," Acquisition Review Quarterly (14), pp. 167-181, 1998.
[32] IBM Global Procurement, "A Corporate View on EProcurement Projecting IBM Through the Supply Chain". State of Iowa, ERP Migration Plan, 2000.

[33] Aberdeen Group, "E-procurement: Don't Believe the Anti-Hype,", Aberdeen Group, Boston, MA, 2001.

[34] K. Eyholzer and D. Hunziker, "The use of the Internet in Procurement", in H. R. Hansen, M. Bichler, and H. Mahrer (Eds), Proceedings of the 8th European Conference of Information Systems, Vienna University of Economics and Business Administration, Vienna, pp. $335-42,2000$

[35] L. Kaufmann, "Purchasing and Supply Management - A Conceptual Framework," in L. Kaufmann and D. Hahn (Eds), Handbuch Industrielles Beschaffungsmanagement: Internationale Konzepte Innovative Instrumente - Aktuelle Praxisbeispiele, Gabler, Wiesbaden, pp. 3-32, 1999.

[36] R. Lamming, "Strategic Procurement Management in the 1990s: Concepts and Cases," Earlsgate Press, Stamford, CT, 1995.

[37] T. Puschmann and R. Alt "Successful use of EProcurement in Supply Chains," Supply Chain Management: An International Journal, Vol. 10, No. 2, pp. 122-133, 2005.

[38] L.C. Giunipero and C. Sawchuk, "E-Purchasing Plus. Changing the Way Corporations Buy," JGC Enterprises, Goshen, N.Y., 2000 